\title{
Does Planning Belong to the Politics of the Past?
}

\author{
Barbara Czarniawska
}

ABSTRACT

KEY WORDS:

\begin{abstract}
According to many authors, so-called "central planning" had disappeared from European countries by 1989 . However, this is by no means certain. Many former centrally planned economies still engage in central planning, in both the private and public sectors. Moreover, there is a striking similarity between so-called "strategic planning" in large private and public units and central planning in a small-sized economy. These similarities and differences are examined in this article using several examples, concluding with city planning. The analysis suggests that city politicians may find useful lessons in organization studies, revealing that while planning has a powerful comforting and tranquilizing function, plans, like tools, need to be abandoned when they are obsolete or cumbersome. Additionally, planners and managers may find it useful to admit that the differences between the private and public sectors are not as large as conventionally assumed and that their activities are always connected to politics.
\end{abstract}

financial markets, equity capital, banking, value at risk (VaR), diversification, risk management, asset-liability management

JEL Classification: $\quad$ M00

\section{The geographical location of central planning}

The title of this section may appear at first blush to be a joke. Is it not the case that everyone knows that central planning was restricted to totalitarian regimes - most recently to pseudo-socialist and communist regimes such as the late Soviet Union and its allies? However, is it really so?

\section{Planning in a centrally planned economy}

Between 1972 and 1975 and again between 1978 and 1980, I participated in a large research project in Poland

Corespondence concerning this article should be addressed to: Barbara Czarniawska, University of Gothenburg, Gothenburg Research Institute P.O Box 603 SE 40530 Gothenburg Övre Fogelbergsgatan 6, Phone: +46 31786 1552, Fax: +46 317865619 , e-mail: Barbara.Czarniawska@gri.gu.se run by a joint team of economists and psychologists. The study included fieldwork: in three head offices of domestic trade in Poland and 49 enterprises (corresponding to the administrative structure of 49 voivodships) subordinated to one of them (Beksiak \& Czarniawska, 1977). Unlike speculative studies based on traditional economic models, this study aimed to describe the actual functioning of a part of a centrally planned economy.

The traditional depiction of a socialist economy defines management system as a set of principles and tools applied by central economic authorities to evoke particular decisions and actions on the part of economic units, as required by a central plan formulated by these authorities. In practice, however, just as there is no perfect competitive market, there was no perfectly centrally planned economy. A scrutiny of the translation of plans into management and then opera- 

sequently exaggerated their needs) and overstated their achievements. HO-T representatives considered these inaccuracies to be the GMs' "insurance policy" - a way of minimizing their failures in advance.

The GMs agreed that the reports were inaccurate, but they explained it differently. Their demands were exaggerated because they were never met (a well-known bureaucratic vicious circle); and the GMs' achievements may have been overstated because of the irrational competition for information among various authorities. The GMs wanted to report on the 5th of each month, but the HO-Ts wanted the report by the 30th of the previous month because it would make it easier to react should anything go wrong. Thus, the end-of-the-month figures were estimated using the sales forecast (notoriously wrong, as wages and salaries were paid at the end of the month). However, the local administrative authorities wanted the information even earlier - by the 27th - and local political authorities had to be first, so they demanded a report by the 25 th. All of this was happening, incidentally, prior to the use of computers for this purpose. The situation generated a boomerang effect; because the performance of an enterprise was exaggerated in forecast-based reports, expectations for the next period were set unrealistically, and the gap between plans and performances grew over time. One of the more ingenious solutions to this problem was to throw the boomerang at the consumer. A continuous shortage of toilet paper made one of the HO-Ts estimate a high demand for this product, and the producer felt compelled to import a new product line. The demand was met in full, but consumers bought incredible quantities of the paper and stored it at home. When the supply became continuous, consumers had no need to buy more, and stores and warehouses held substantial quantities of toilet paper. Another solution was called for: although toilet paper could have been in continuous supply, it was delivered irregularly, so that consumers returned to their hoarding habits.

I was given an opportunity, however, to observe central plans that worked well - in US retail corporations that I deemed to be roughly equivalent to the organisations that I studied in Poland.

\section{Planning in a market economy}

Between 1980 and 1981, I interviewed 40 representatives of corporate headquarters (CHQs) and CEOs or their equivalents in divisions located in Massachusetts (Czarniawska, 1985). Many of these corporations were the same size as the Polish Head Offices of Trade, and they could have 49 or more subsidiaries.

To put it briefly: there were central plans in US corporations, but this central planning looked different.

In the corporations that I described under the label of Autonomy (Czarniawska, 1985), the CEOs set their own objectives based on information collected from both above (the general preferences, trends, and directions of expansion favored by their CHQs) and below (the aspirations and resources of subordinates in their own division). These plans were subsequently submitted for evaluation at the CHQs, and when disagreements arose, intensive negotiations began that did not always reach consensus. Ultimately, the CHQ usually allowed the CEOs to make their own decisions but then controlled their actions "very, very tightly". In general, the CEOs believed that the main concern of the CHQs was to create conditions that facilitated the achievement of objectives, and their primary responsibility was to advise and guide. The final outcomes were one- and five-year plans for the entire corporation. What did the CEOs think of this system?

"It's a strength because you have a lot of people convinced that they have their own responsibility, and this is very efficient. It's a weakness, because if you're under competitive pressure, or if there is a major technology that breaks through, the tendency of people is to optimize the space they're in, and not to try to go into another space" (Czarniawska, 1985, p. 20).

In other words, the delegation of responsibility produced risk-avoiding behavior, just as the fear of punishment did for the Polish GMs.

Half of the corporations I studied had a planning process that differed from that of the Autonomy corporations, and I labelled these type of process Control. In these corporations, the CEOs received broad corporate guidelines concerning strategic plans; a list of financial and qualitative objectives; and lists of restrictions, resources, critical areas, and general scenarios - the possible future condition of the economy, for instance. Equipped with these lists, the division initiated a bottom-up planning process. This was followed by a negotiation process, induced primarily by negative reactions from $\mathrm{CHQ}$ s over what was per- 

strategic planning also plays a clearly political role: reproducing the conditions of hierarchically organized capitalist society, normalizing the existing structures of western societies, and universalizing the goals of the dominant elites. Strategy-formation patterns are difficult to change, as they are "founded on real economic, social or political conditions" (p. 32). Thus it is appropriate to follow the unusual path indicated by de Certeau (1988), who suggested that whereas strategy expresses what bosses want, it is through tactics that subordinates find ways to circumvent or straightforwardly resist it (de La Ville \& Mounoud, 2003). "Strategies (...) conceal beneath objective calculations their connection with the power that sustains them from within the stronghold of its own 'proper' place of institution" (de Certeau, 1988, p. 20). Thus whereas strategists produce plans and budgets, those who are to implement them translate and transform them for their use, creatively mixing routines and improvisation. "... [A] tactic depends on time - it is always on the watch for opportunities that must be seized 'on the wing.' Whatever it wins, it does not keep. It must constantly manipulate events in order to turn them into 'opportunities"' (de Certeau, 1988, p. 19). This quote captures the practices of the Polish GMs, whereas the US CEOs, especially those grouped under the Autonomy label, can be seen as strategists, with tactics being shifted further down the hierarchy.

Thus planning is always related to politics - on several levels - and its connection to performance is always complex. Not surprisingly, this observation is corroborated most strongly in public sector organizations, which I now intend to exemplify using urban planning.

\section{Urban planning: Is chaos beautiful?}

Can the analogy between economic planning and urban planning hold? I would claim that the two of the traits of planning listed above are transferable: urban planning is always related to politics, and its connection to performance is always complex. However, the position of urban planners cannot be compared to the positions of HO-Ts or CHQs: they are more similar to the Polish GMs, exposed to sometimes conflicting expectations from HO-Ts (mostly professional) and local authorities. The real difference, however, is the heterogeneity of contractors that implement the plans.
Although 49 is a substantial number of enterprises or divisions, the enterprises are similar, as are the divisions; they have the same owner and share most of their administrative routines. The political and economic expectations faced by urban planners may be fairly coherent, but a large number of units, which are, in turn, subject to a variety of strategies and tactics, must then interpret the plans. Nevertheless, political and economic expectations being translated into plans represent a powerful "calculus of force-relationship" (de Certeau, 1988, p. 19), and the process of urban planning can be examined by comparing and contrasting it to economic planning.

I now consider two extreme examples: what I call total planning and a plan-less city.

\section{Total planning}

The usual examples of total urban planning are taken from post-World-War-II Europe, especially the parts of Europe such as Warsaw that became forced allies of the USSR. However the idea of total urban planning can be said to be as old (or as new) as modernity itself, and the model examples are Petersburg, Haussmanian Paris, and the French colonies.

In 1703, Peter the Great conquered a city belonging to the Swedes, located where the Neva flows into the Baltic Sea. He gave it his own name and decided to make it his "window on Europe". It became the Russian capital in 1712, and the best specialists of Italian baroque were employed to give it a modern and western look. Drafted by Peter in two weeks, as the story goes, it was planned from the beginning to be an imposing capital; a regular street pattern was interspersed with impressive squares and broad avenues radiating from the Admiralty Shipyard, one of the Peter's first investments. At the end of the century, Petersburg counted 220,200 inhabitants, more than one-third of whom were employed by the administration or the military.

It was not until the 19th century that the results of Peter's urban design could be truly appreciated. Much against the will of his subordinates, he created a truly modern city, much like the one described by Thernström and Sennett (1969).

For the writer Gogol, there was no greater contrast between cities than that between the Northern City of Petersburg and the Southern City of Rome (Fanger, 1965). Petersburg represented an "unnatural" creation 

These two terms reflect the assumption that both local and central government are "self-governments" - in other words, democratic. Accordingly, the differences lie in the locus of power, not in its character. The Polish terminology alludes to the fact that the central government may be, and historically has typically been, of a non-democratic nature.

State control was introduced in 1950, and all public property was turned over to the state treasury. In the case of Warsaw, this was peculiar property, as 85 per cent of the value of the city's real estate had been demolished (Wyganowski, 1993, p. 11). Of the 957 historical buildings in Warsaw, 782 had been totally destroyed, 141 partially destroyed, and only 34 untouched (Cullen, 1994, p. 36). The territory of Warsaw was treated as an area open to all types of urbanistic projects (in one particularly critical opinion, "the city planners got absolute power", quoted in Czarniawska, 2000, p. 19), and to this end a special decree allocated private grounds and buildings first to the city, and later to the state.

Residents of Warsaw expressed a variety of emotions about some of the urbanist projects in their city, including the (in)famous Culture Palace, previously the symbol of hated Soviet oppression and then rehabilitated as a historical monument, a document of its historical period. It is most likely Warsaw wit that spawned the story of the Soviet Union offering a choice between the palace and a metro; the authorities at that time, ever eager to please Big Brother, chose the palace. Sophisticated people turned up their noses at the reconstruction of a fake Old Town, but it was a project that appealed to the emotions of both the resident population and tourists. The reconstruction of the Royal Castle in 1974 did not evoke as many positive emotions as did the Old Town. Some reevaluations have also occurred over time. The much-derided MDM (Marszalkowska Street residential district) and other monuments of the Stalinist era turned out to be "not so bad", whereas the miracle of modernity from the 1970s, the Ursynow district, was predicted, with some exaggeration, to become a slum.

In a word, every urbanistic project in Warsaw created a wave of emotions, sometimes positive, sometimes negative; but over time and as contacts with foreign countries intensified, they were increasingly negative.

After the pivotal year of 1989, the first central government (that of Tadeusz Mazowiecki) and the two that followed focused a great deal of attention on a bill for the reprivatization of land in Warsaw. The idea of self-government was also obvious but the form that it would take was highly problematic. Warsaw was excluded from the Polish Local Government Act to resolve the problem of reprivatization. The special treatment of Warsaw in 1945 compelled equally special treatment in 1990. The act provided for a uniform conception of the municipality as a sovereign administrative entity, irrespective its size or location. In Warsaw, a Union of District Municipalities consisting of seven district municipalities (later to include the Municipality of Ursus) was created on the assumption that local problems, including reprivatization, would be easier to solve locally, whereas the union should be responsible for "general tasks", which were not specified in the act - most likely under the expectation that they would be settled through experience and negotiations. The question of the municipal economy did not seem to be difficult at first, but later a discussion began over the services it should include, and which services were better left to district management or purchased from private companies. In practice, the municipal economy came to comprise waterworks and the sewage system, public transportation, garbage collection, and district heating and gas, although the utility that produces them serves not merely the city, but the whole county. A few years later, the city government took over responsibility for the state of Warsaw's streets from the county governor. Some district municipalities took over certain spheres of activity, such as schools.

Martial law witnessed the appearance of citizen committees - groups of individuals who attempted to maintain order locally amid the growing confusion. Almost automatically, the same people became councilors and mayors after the self-government election of 27 May 1990. They "took over the old structure with a task to continue" (Czarniawska, 2000, p. 20), and the general feeling was that a new structure and new management rules had to be developed. This necessity became increasingly clear while the new administration gained experience and new problems accumulated. Slowly but surely, a politicization of the municipal cadre began. Regardless of the councilors' political stripes, planning was not an activity to be cherished. Warsaw was again to become a "modern city", but along the lines sketched from 1919 to 1939 , not due to any total 
planning. Moreover, it seemed obvious that such key matters as infrastructure should be centrally planned and managed (Czarniawska, 2002).

It may appear, therefore, that the idea of "total city planning" belongs to the history of modernity, which itself is becoming ancient. Postmodernity, as it is known, returned to pre-modern values, especially in architecture. It is therefore appropriate to examine Gogol's ideal city of the South: Rome.

\section{A plan-less city}

During my study of city management in Rome (Czarniawska, 2002), my interlocutors confided in me with what I read as a mixture of shame and pride - that the city did not have a traffic system. There was no urban transport plan, and neither the tariffs nor the networks were integrated. As one interviewee told me:

[To understand it], you have to go back centuries, to the creation of Municipalities and Dominions, that is 1300-1500, when the empires disintegrated. From then on the local particularism was of the utmost importance, the so-called villageism, which drags on until today. In the city, and even in the region, there are clearly areas that are economically and culturally homogeneous and that could be more rationally planned and managed. This is, alas, excluded by administrative divisions. The regional authorities were supposed to take care of these problems, but they did not (Czarniawska, 2002, p. 28).

The problem was not only spatial; attempts at city planning in Rome reveal a temporal aspect that was not present in previous examples in which the political regime remained stable - at least during a typical planning period. Recently, I studied the generally abortive plans of urban renewal directed at the Roman district of Magliana, which extends along the Tiber between Fiumicino Airport and the center, thus representing a potentially attractive part of the city. At present, however, it is a mixture of industrial landscapes, dilapidated plots of unknown ownership, haphazard camping places, and various sport activities.

I began my story with a excerpt from Municipal Council Resolution no. 9 from 8 January 2001, which contained a decision to undertake 11 urban recovery projects - among them "Magliana" (Czarniawska, 2010, pp. 422-423):

\section{THE MUNICIPAL COUNCIL DECIDES:}

- to adopt a definite Urban Recovery Program related to the location "Magliana"(...);

- to publish this Program, including various urbanistic solutions, and to collect comments concerning the possible consequences of such solutions, as stipulated by art. 49 , 2 of the L.R.L. n. 38/1999;

- to begin formulating and completing the necessary agreements between the Municipality and the Lazio Region, in terms of art. 3 of the protocol of understanding reached by this Council on 17 March 2000, the aim of which the definitive approval and financing of the Urban Recovery Programs, and to provide the Mayor with a mandate to conduct the agreements described above, in the terms of art. 24, 4 of the Statute of the Municipality of Rome;

- to assent to the private intervention projects related to the Urban Recovery Program, as represented in the relative urbanistic projects and technical-economic charts appended in $\mathrm{B}$, which constitute an integral and substantive part of the present resolution; (...)

- to adopt a contractual arrangement between the Municipality of Rome and the private entities offering projects, which is appended as $\mathrm{C}$ and constitutes an integral and substantive part of the present resolution;

- to insert the public works planned within the Urban Recovery Program into the biannual and triennial budgets for public works, including them in annual and triennial reports as direct costs for the same municipal administration, as decided by Financial Plans for Urban Recovery Programs; (...)

- to give the Municipal Government the authority to control the quality of the public works at the point of approving their plans. (...)

The following was attached to the Resolution: a "Tab. 5. The financial plan of interventions", containing item "OP13. Expropriation transfer and realization of the park 'Pian Due Torri'. Total sum: € 9,296,224.18”.

The Resolution and the plan were presented to the Lazio Region for approval and financing. The 
Region demanded more specific plans and projects, and for this purpose, two special organizational units were created in 2006: VI, which was dedicated to projects, and VII, which was dedicated to the management of projects. What transpired from 2001 to 2005 is difficult to ascertain (a similar uncertainty concerned the years 1993-2001; in accessible documents, these periods are covered by the label "gestation of the program"), but toward the end of 2007, there were positive developments. The following is a message from the Department of Urban Planning from 28 February 2007:

(...) The program concerns the area stretching between the Tiber and the tracks of the local train that connects Orte to Fiumicino Airport. Magliana, one of the most densely populated districts of Rome, suffers from being isolated from the rest of the city, to which it is connected only by the crowded bridge in the direction of EUR, by Isaac Newton Street and by passages under the train tracks that are totally inadequate for the present level of traffic. The old suburbs are surrounded by the residential area constructed in the 1960s, and are interspersed with various shanties originally constructed for some industrial or commercial purposes, but now abandoned, and by open spaces lacking any function. The interventions planned within the program are distributed along two axes: the green axis, beginning at Villa Bonelli Park, crossing Pescaglia and Cutigliano streets, arriving at the gardens at Castiglion Fibocchi Street and from there to the new Tiber River park; and the axis of services and new functions, which will connect the district of Roma Tre University with San Paolo with a new pedestrian bridge, and will cross the district passing by the public market at Lari Street, terminating in the area of Greve Street, where it will concentrate various commercial, cultural, and touristic activities. The system of internal viability and the connections with the city will be realized by using and developing the potential of the existing system of train lines, but will also involve restructuring and completing important traffic nodes between Isaac Newton Street, Magliana Bridge, Motorway Rome Fiumicino, and the streets of Magliana and Magliana Nuova. In total, the planned interventions - 22 public and 10 private - will affect an area of 170 hectares, inhabited by 30000 persons, and require an investment of $€ 155$ million. The projected time for the adoption of the Program and the stipulation of the related Agreement on the Program and the realization of the public works is a minimum of 12 months and a maximum of 60 months depending on the complexity of the works included. (Czarniawska, 2010, pp. 423-424)

Part of this program was the Pian Due Torri Park, called Tiber River Park in this document. By January 2008, one of the two main Italian dailies, La Repubblica, confirmed the changes to the fate of Magliana:

\section{"Magliana, a park on the river"}

A green area of 8 hectares will uncoil along the loop of the Tiber from the Magliana Bridge to the Industry Bridge, i.e., on the terrain previously occupied by illicit campers. The project also includes the creation of a true green lung for the city: the park "Pian Due Torri". A public work costing $€ 9$ million, financed by the Lazio Region, will improve the quality of life of the inhabitants (...). At present, car-body shops, various deposits, and other commercial enterprises occupy the area where, by the end of the year, the works necessary to make a park will begin. A total of 43 companies will be moved to other places (...). As to other projects along the loop of the river, these will be discussed with the inhabitants. The present plans include a bicycle and walking track, an area for dogs, a health track with appropriate equipment, new illumination to make the area more secure, a playground for children, a picnic area with tables and benches, a football arena, and a landing for boats that sail the Tiber. The works and the security arrangements will be open to a public tender directed to the cooperatives that wish to undertake the job. (Czarniawska, 2010, pp. 424)

How were those decisions and plans translated into actions? Partly, I could see such actions myself, running daily on the health track; partly, they have been commented upon and reported by the inhabitants and their associations. The sum of money dedicated to the project has not changed in seven years; one can imagine that 
the prices did, however. Next, 43 companies were to be moved to other places. But which companies? The area was infamous for a large number of illicit enterprises that had been discovered and closed down - an illicit kennel, for example - but there were many shanties the purposes of which have been forgotten and many dilapidated properties with unclear ownership.

It was clear what would remain. There were already two sports arenas; one belonged to the nearby parish and the other, which was likely to be upgraded, belonged to the municipality. There were also two paddocks and a horse track. These objects already existed; they needed only to be translated into the new park. What was happening and what was changing?

Citizens belonging to the Association for Educational Education started an action: "Let's clean our park". Baskets were located along the Tiber, and the inhabitants were encouraged to wear rubber gloves and join in the cleaning action, which began on 14 July and was to continue for "some days" between 7.00 and 8.00 in the morning. No connection to planned municipal actions could be discerned.

The municipality undertook some actions, however. By 2007, small metal fences were placed on the walking track, making it impossible to enter the embankment, and thereby stopping the Romany people who camped there with their caravans. Yet it is uncertain if the new city administration performed this action under the heading of their flagship program, "Safety in the City" (aimed at eliminating Romany encampments within the city centre) or as part of the Magliana Urban Recovery Program.

Suddenly, solar panels arose in the middle of the route. The initial speculation was that the structures were to be the starting point of a funicular that would cross the river, toward Roma Tre University. The character of the construction, although not its purpose, soon became clear. Perhaps the panels were to provide energy for the lamps along the health track? At present, the area under the panels is used for parking, and the reeds have overgrown the panels.

One day in January 2008, a crew in municipal uniforms arrived at the end of the health track and began to mark the places where the fence preventing the reeds from overgrowing the track should be placed, continuing the existing fence. Nothing transpired throughout February and March, but one Monday in April they returned, and installed five meters of fencing. Their work was observed with great interest by the Romany children, who were still living there. By September 2008, the remaining markings were already vanishing. The benches and new garbage cans are in place to this day, somewhat worse for wear.

Opposite the embankment is the residential side, which also formed part of the Urban Recovery Project. Some of the buildings (there are apartment buildings, two schools and one home for the elderly) are extremely attractive, and would become even more attractive if the park project were realized. A construction entrepreneur undertook the renovation of one house, previously burnt (reeds along the river often catch fire), but apparently ran out of money. The renovation came to a halt, it seems, in the middle of a working day. Until May 2008, the external elevator remained halfway down; some windows have glass in them, and others do not. The building was finished by 2010, and a municipal administrative office moved in.

Squatters occupy yet another building, standing between two posh buildings. Previously, some of them were Romany families; at present, judging from the Trotskyist and Maoist flags on the balconies, the inhabitants constitute a different group.

Within the framework of the URP Magliana, the municipality built a playground for children in the middle of the residential street - a peculiar playground. A parking lot is located on one side; cars park there during the week, and teenagers rule during the weekend. The playground is covered with asphalt. Perhaps asphalt is needed for some types of games, but still, it breaks one's heart to see that just on the other side of the playground, near the river, there is a lush, almost tropical, private area with palms and the like. Furthermore, there is no space between the track and the parking lot on one side, and the track and the playground fence on the other, so cyclists and walkers who happen to arrive at the same time create a traffic jam.

There is also the question of whose track it is. There is a path running along the river on the embankment; now that the Romany people are gone, 
increasing numbers of dog owners go there. Not all of them, however. Many remain on the health track, and not many of them carry plastic bags. This is the end of the track, or rather the end of the park project, as the track continues on the other side of the river.

My account of the project is tinted by my Swedish perspective on such things as city planning. I imagine (most likely wrongly) that, at home in Gothenburg, I would know exactly what is and is not being done, and I would be able to follow the realization of the project from beginning to end. If something did not go according to plan, my local newspaper would explain it to me the next day or at least two days later. I often had to correct the locals in Magliana, however, who claimed that "nothing was being done". Some things were being done, but the choice of projects, their locations, their timing, and why they were incomplete was not clear. The pedestrian bridge had been built; although, according to the sceptical locals, it did not lead from the Basilica of San Paolo to the Roma Tre University, but "from nowhere to nowhere" (here the locals are correct). It was also difficult to see any connections between the projects.

In 2008, the opposition won the national elections and the local elections in Rome. Taking office in June 2008, Mayor Gianni Alemanno and his allies announced that there was an "enormous hole" in the city's finances. "Bluff and mystification", was the reply of the opposition (Corriere della Sera, 2008-06-16 in Czarniawska, 2010, p. 434). A thorough investigation was promised. On 29 September 2008, Alemanno presented the results, supported by his Treasurer:

"Plan of retreat, hour of truth".

(...) "Today is the day of truth and responsibility

I hope, and not of the useless and irresponsible debates". Thus the Mayor begins his speech to the City Council. The report confirms that the total debt of the Municipality amounts to $€ 8,646$ billion. (...) (Messagero Cronaca di Roma, 200809-30 in Czarniawska, 2010, p. 434).

What about Urban Recovery Projects? The mayor proposed to the Council a list of severe cuts:

(...) These are only some of the cuts the Alemanno administration proposed to the Council in conjunction with the report on finances prepared by Treasurer Ezio Catiglione in a proposal that yesterday began to work its way through the Council. A cut of 677 million, 358 from current expenses and 319 from investments, among which was a series of projects (for a total of 54 million) planned by the Center-Left that were abandoned by the Center-Right. In recompense, $€ 800$ million for the equipment of city police (...), 200 million for the Marzano Committee [for the Future of the City of Rome]; and even 740000 for the office of the Mayor: "A real scandal, says an angry [member of the opposition], people die of hunger and these people use one and half billion old lire to buy Christmas presents and give ostentatious dinners" (La Repubblica, 2008-09-19, in Czarniawska, 2010, p. 434).

What of the URP Magliana? The Resolution of the Council (nr 66 of 12/13 December 2008, containing the Financial Plan for 2009-2001, 113 pages) mentioned neither Magliana nor Pian Due Torri, but the introduction to the financial plan, item 4.14, "Policy for public works, urban maintenance and peripheries", stated:

Rome is a city that grew urbanistically with no rules or against the existing ones. One can observe, on the one hand, a continuous increase of so-called "spontaneous" construction, and on the other, grand investments in residential areas beyond any effective planning, accompanied by an excessive proliferation of mega-shopping centers. All this lowered the urban quality and above all reversed the "normal" order of things: the necessary infrastructure follows large residential projects, not the other way around. Additionally, we have to report a total collapse of the realization of urban recovery projects in zones " $O$ " (...), and many "empty places" -centers of illicit activity for which no recovery plans have ever been formulated. In this situation, absolute priority must be given to the realization of urban plans; and the actions of City Administration will be based upon the following grand pillars:

1. Safety margins of urban re-qualification (...)

2. Architectural infrastructure (...)

3. Urban restructuration (...)

4. Urban maintenance (...)

(Czarniawska, 2010, p. 434)

Pian Due Torri program may or may not be classified under the first "pillar". On the one hand, the money 



\section{References}

Allmendinger, P., \& Tewdwr-Jones, M. (2002). The communicative turn in urban planning: Unravelling paradigmatic, imperialistic and moralistic dimensions. Space and Polity, 6(1), 5-24.

Beksiak, J., \& Czarniawska, B. (1977). Enterprise response patterns under the socialist management system. Oeconomica Polona, 2, 211-228

Bragd, A. (2002). Knowing management: An ethnographic study of tinkering with a new car. Göteborg: BAS Publisher.

Connerton, P. (1989). How societies remember. Cambridge, UK: Cambridge University Press.

Cullen, M. S. (1994). Alles Unglück dieser Erde: Warschau. In M. Mönninger, (Ed.), Last exit downtown. Gefahr für die Stadt. (pp. 144-150). Basel: Birhäuser Verlag.

Czarniawska, B. (1985). Controlling top management in large organizations. Aldershot, UK: Gower.

Czarniawska, B. (2000). A city reframed. Managing Warsaw in the 1990s. Reading. UK: Harwood Academic Publishers.

Czarniawska, B. (2002). A tale of three cities, or the glocalization of city management. Oxford, UK: Oxford University Press.

Czarniawska, B. (2009). How institutions are inscribed in technical objects and what it may mean in the case of the Internet. In F. Contini, \& G. F. Lanzara (Eds.), ICT and innovation in the public sector. European studies in the making of e-government. (pp. 49-87). Basingstoke, UK: Palgrave Macmillan.

Czarniawska, B. (2010). Translation impossible? Accounting for a city project. Accounting, Auditing and Accountability Journal, 23(3), 420-437. de Certeau, M. (1988). The practice of everyday life. Berkeley, CA: University of California Press.

de La Ville, V.-I. \& Mounoud, E. (2003). How strategy can be a practice? Between discourse and narration. In B. Czarniawska, \& P. Gagliardi, (Eds.), Narratives we organize by (pp. 95-113). Amsterdam: John Benjamins Publishing Company.

Fanger, D. (1965) Dostoevsky and romantic realism. Cambridge, MA: Harvard University Press.

Jacobs, J. (1961). The death and life of great American cities. New York, NY: Random House.
Listerborn, C. (2007). Who speaks? And who listens? The relationship between planners and women's participation in local planning in a multi-cultural urban environment. GeoJournal, 70(1), 61-74.

Rabinow, P. (1989) French Modern: Norms and forms of the social environment. Cambridge, MA: The MIT Press.

Soros, G. (2011). My philanthropy. New York Review of Books, 58(11), 12-16.

Thernström, S. \& Sennett, R. (Eds.). (1969). Nineteenth-century city-essays in the new urban history. New Haven, CT: Yale University Press.

Weick, K. E. (1979). The social psychology of organizing. Reading. MA: Addison-Wesley.

Weick, K. E. (1996). Drop your tools: An allegory for organization studies. Administrative Science Quarterly, 41(2), 301-313.

Whittington, R. (1993). What is strategy and does it matter? London: Routledge.

Wren, D. A., \& Bedeian, A. G. (2004). The Taylorization of Lenin: rhetoric or reality? International Journal of Social Economics, 31(3), 287-299.

Wyganowski, S. (1993). Jutro Wielka Warszawa. [Tomorrow Great Warsaw]. Warsaw: Związek Dzielnic-Gmin Warszawy. 
